УДК 621. 316. 543

A. V. Bliznyakov

Candidate of technical sciences, docent Zaporizhzhja national technical university

\title{
STATIONARY THERMAL BEHAVIOR ANALYSIS OF CURRENT- CARRYING SYSTEMS OF POWER ELECTRIC AND ELECTRONIC EQUIPMENT
}

\begin{abstract}
Computation method of stationary thermal conditions determination of power electric and electronic equipment of current-carrying systems is proposed. The method differs in considerable versatility and takes into account a great number of various components with distinctive conditions of heat release and heat transfer in complex current-carrying system.
\end{abstract}

Key words: current-carrying component, current-carrying system, thermal behavior, heating, temperature-rise, heat flux, thermal resistance.

It is known that current-carrying systems of power electric and electronic equipment are for the most part thermally complex and inhomogeneous in structure. For example, current-carrying system of switching apparatus usually includes a few conductors, which may distinguish in geometrical configuration, material as well as conditions of releasing thermal energy and their driving out to environment. Current-carrying system of switching apparatus includes also contact joints, switching contacts, power semiconductor devices (PSD-based switching apparatuses). The components of this type are concentrative (focused in small volumes) sources of thermal energy.

At the same time in practice of designing current-carrying systems of power electric and electronic equipment thermal behavior analysis in nominal duty is frequently made using simplest models. One of such models is the current-carrying system that consists of two half-infinite rods having contact with end surfaces [1]. It is amply evident that application of such models does not allow taking into account inhomogeneity of the current-carrying system and is permissible only for scoping calculations performed at early stages of designing the equipment (research work), when contact pressure, material of the current carrying parts, its dimensions etc. are decided. At later design stages (development work), when working detail drawings of the current-carrying system are developed, the mockups and prototypes are made and tested, such models are entirely not applicable. It is well known that at these stages the current carrying parts are subjected to repeated constructive modifications, undergo numerous temperature-rise tests in rated duty. In the process, constructive changes insignificant at first glance may have a considerable effect on thermal behavior of the current-carrying system. It is also known that performance of the temperature-rise tests of electric and electronic equipment in rated duty is very expensive in respect to both time and finance resources. Performance of repeated tests, when the construction of the current-carrying parts is changed, leads to significant economical losses and may be finally inefficient. In this situation the combination of mockups temperature-rise tests (in nominal duty) and précised (detailed) calculations with application of the model taking into account the structure of developed current-carrying system can be in most degree very suitable. This approach would allow estimate thermal behavior of numerous constructive variations of the currentcarrying system, and so significantly reduce expenses in temperature-rise tests performance and, finally, find out optimal constructive variant.

It is known that in inhomogeneous current-carrying systems heat is transferred not only in radial direction from current-carrying parts to environment, but axially from more heated current-carrying component to less heated one. Consideration of equalizing heat fluxes makes impracticable the task to derive simple expressions for engineering thermal calculations of thermally inhomogeneous current-carrying parts. Nevertheless, there is a number of methods that enable to calculate thermal behavior of inhomogeneous conductors [2-5]. General shortcoming of the mentioned methods is their limited application. For example, expressions for calculation of heating the conductor with variable crosssection [2-4] can be applicable only for current-carrying parts with no concentrative thermal sources (switching contacts, contact joints, PSDs etc.). Method that enables to calculate temperature-rises in the neighborhood of contact points of on-load tap changer current-carrying system including sliding contact unit is developed [5]. However, the current method is applicable only for particular case and does not takes into account inhomogeneity of the currentcarrying system and all available contact joints to the full.

The proposed method saves methodology and principal approach of existing methods on the whole [2-5]. Nevertheless, it differs in higher degree of universality and can be applied for computational estimation of thermal behavior of any complicated thermally inhomogeneous current-carrying systems. At the same time considered current-carrying system may include practically any number of concentrative thermal sources (contacts, contact joints, power semiconductor devices etc.). The essence of this method is in following. An inhomogeneous current-carrying system is subdivided into a number of typical components 
(sections), such as, half-infinite current-carrying elements, current-carrying elements with finite length, contact joint between different current-carrying elements, switching contacts, power semiconductor devices and such like. The equalizing heat fluxes are determined for each component (section) at their boundaries. Then, using condition of temperature field continuity, required number of algebraic equations is setup. Their solution gives unknown temperature-rises at the boundaries of the sections and temperature distribution along a whole current-carrying system.

To determine equalizing heat fluxes let us consider most typical sections of power electrical and electronic equipment current-carrying systems. It is known that stationary thermal behavior defined by steady state distribution of temperature $\vartheta$ with length of a conductor having invariable cross-section and equable heat exchange conditions with environment is described by differential equation of second order as follows [2]:

$$
\frac{d^{2} \vartheta}{d x^{2}}+a^{2}\left(\vartheta-\vartheta_{\text {st }}\right)=0,
$$

where $\vartheta_{\text {st }}, a$ are the equation constants defined by the parameters of the current-carrying element:

$$
\begin{gathered}
\vartheta_{\mathrm{st}}=\frac{\frac{I^{2} \rho_{0} \kappa_{\mathrm{ad}}}{q}+\frac{\vartheta_{0}}{r_{\mathrm{th} \Sigma}}}{\frac{1}{r_{\mathrm{th} \Sigma}}-\frac{I^{2} \rho_{0} \kappa_{\mathrm{ad}} \alpha}{q}} ; \\
a=\sqrt{\frac{1}{\lambda q}\left(\frac{1}{r_{\mathrm{th} \Sigma}}-\frac{I^{2} \rho_{0} \kappa_{\mathrm{ad}} \alpha}{q}\right)},
\end{gathered}
$$

where $I$ is the load current continuously flowing through the current-carrying element; $\kappa_{\text {ad }}$ is additional losses factor in the conductor; $q$ is cross-sectional area of the conductor; $\vartheta_{0}$ is the ambient temperature, ${ }^{\circ} \mathrm{C} ; r_{\text {th } \Sigma}$ is average with length of the current-carrying element specific thermal resistance between conductor surface and environment; $\lambda$ is heat conductivity of the conductor material; $\rho_{0}$ is resistivity of the conductor material at $0^{\circ} \mathrm{C} ; \alpha$ is resistivity thermal coefficient of the conductor material.

Differential equation (1) is in strict sense non-linear as parameters $\vartheta_{\text {st }}$ and $a$ included to it are dependent upon the temperature on the conductor surface. If this dependence in first approximation is not taken into account, its solution can be derived by the classic method. It depends on the manner of predetermining the boundary conditions. Let us consider main types of sections which are most typical for currentcarrying systems of power electric and electronic equipment.

For the section of finite length shown in fig. 1 the boundary conditions are predetermined by the temperatures at the section boundaries:

$$
\vartheta(0)=\vartheta_{1} ; \vartheta(l)=\vartheta_{2},
$$

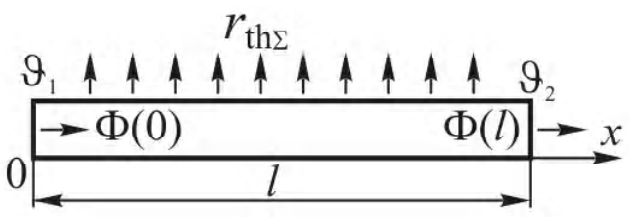

Fig. 1. Current-carrying element of finite length

where $l$ is the section length; Solution of equation (1) in terms of boundary conditions ( 3 ) will be expressed as:

$$
\vartheta=\frac{\left(\vartheta_{1}-\vartheta_{\mathrm{st}}\right) \operatorname{sh}[a(l-x)]+\left(\vartheta_{2}-\vartheta_{\mathrm{st}}\right) \operatorname{shax}}{\operatorname{shal}}+\vartheta_{\mathrm{st}} .
$$

Using Fourier's law the equalizing heat fluxes at the section boundaries can be written in the following form:

$$
\Phi(0)=u \vartheta_{1}-v \vartheta_{2}+s ; \Phi(l)=v \vartheta_{1}+u \vartheta_{2}-s,
$$

where $u=a \lambda q \frac{\text { chal }}{\text { shal }} ; v=\frac{a \lambda q}{\text { shal }} ; s=\vartheta_{\text {st }}(v-u)$.

For the half-infinite section shown in fig. 2 the boundary conditions are predetermined as follows:

$$
\vartheta(0)=\vartheta_{\mathrm{b}} ; \vartheta(\infty)=\vartheta_{\mathrm{st}} ;\left.\frac{d \vartheta}{d x}\right|_{x=\infty}=0 .
$$

The temperature distribution along the conductor will be expressed as follows:

$$
\vartheta=\left(\vartheta_{\mathrm{b}}-\vartheta_{\mathrm{st}}\right) e^{-a x}+\vartheta_{\mathrm{st}}
$$

The equalizing heat at the section boundary (that is at $x=0$ ) will be expressed as

$$
\Phi(0)=a \lambda q\left(\vartheta_{\mathrm{b}}-\vartheta_{\mathrm{st}}\right)
$$

Contact thermal behavior within constriction region for accepted spherical model is described by the following differential equation [2]:

$$
\frac{d^{2} \tau}{d r^{2}}+\frac{2}{r} \frac{d \tau}{d r}+\frac{I^{2} \rho}{4 \pi^{2} \lambda r^{2}}=0
$$

For constriction region of the contact formed by contactpieces of different materials the boundary conditions will be as follows:

$$
\begin{aligned}
& \left\{\begin{array}{l}
\tau_{1}(\infty)=\tau_{\mathrm{c} 1} ; \quad \tau_{2}(\infty)=\tau_{\mathrm{c} 2} ; \quad \tau_{1}(a)=\tau_{2}(a)=\tau_{\mathrm{c} . \mathrm{sp}} \\
-\left.2 \pi \lambda_{1} r^{2} \frac{d \tau_{1}}{d r}\right|_{r=\infty}-\left.2 \pi \lambda_{2} r^{2} \frac{d \tau_{2}}{d r}\right|_{r=\infty}=I^{2} R_{\mathrm{c}} .
\end{array}\right.
\end{aligned}
$$

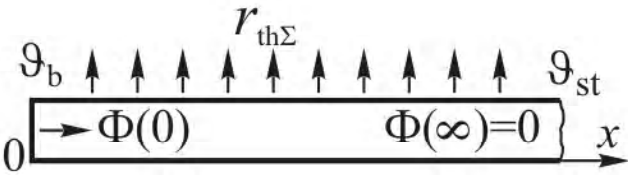

Fig. 2. Half-infitine current-carrying element 
where $\tau_{1}$ and $\tau_{2}$ are the temperature-rises within constriction region of the elements forming given contact; $\tau_{\mathrm{c} 1}$ and $\tau_{\mathrm{c} 2}$ are the temperature-rises at the boundaries of the contact constriction region; $b$ is the contact spot radius; $R_{\mathrm{c}}$ is the contact resistance; for a contact formed by dissimilar materials according to spherical model it will be evaluated by the following formula [2]:

$$
R_{\mathrm{c}}=\frac{\rho_{1}+\rho_{2}}{2 \pi a}
$$

where $\rho_{i}, \lambda_{i}$ is resistivity and thermal conductivity, respectively, of the contact material (on the current-carrying system sections in the current lines constriction region).

Solution of differential equation (9) with boundary conditions (10) gives the expressions for equalizing heat fluxes at the boundaries of the contact constriction region:

$$
\left\{\begin{array}{l}
\Phi_{1}(\infty)=s_{1}-s_{12}\left(\tau_{\mathrm{c} 1}-\tau_{\mathrm{c} 2}\right) \\
\Phi_{2}(\infty)=s_{2}+s_{12}\left(\tau_{\mathrm{c} 1}-\tau_{\mathrm{c} 2}\right) .
\end{array}\right.
$$

where

$$
\left\{\begin{array}{l}
s_{1}=\frac{I^{2} R_{\mathrm{c}}}{\lambda_{1}+\lambda_{2}} \lambda_{1}\left(1-\lambda_{2} G_{12}\right) \\
s_{2}=\frac{I^{2} R_{\mathrm{c}}}{\lambda_{1}+\lambda_{2}} \lambda_{2}\left(1-\lambda_{1} G_{12}\right) \\
s_{12}=\frac{\lambda_{1} \lambda_{2}\left(\rho_{1}+\rho_{2}\right)}{\left(\lambda_{1}+\lambda_{2}\right) R_{\mathrm{c}}} ; \\
G_{12}=\frac{1}{2\left(\rho_{1}+\rho_{2}\right)}\left(\frac{\rho_{2}}{\lambda_{2}}-\frac{\rho_{1}}{\lambda_{1}}\right)
\end{array}\right.
$$

The temperature-rise at the contact spot in this case will be expressed as follows:

$$
\tau_{\mathrm{c} . \mathrm{sp}}=\frac{I^{2} R_{\mathrm{c}}^{2}}{2\left(\lambda_{1}+\lambda_{2}\right)\left(\rho_{1}+\rho_{2}\right)}+\frac{\lambda_{1} \tau_{\mathrm{c} 1}+\lambda_{2} \tau_{\mathrm{c} 2}}{\lambda_{1}+\lambda_{2}} .
$$

As known, thermal behavior of power semiconductor devices operating continuously under load is mainly dependent upon thermal resistances of their individual heat sinks. There is no doubt that most part of thermal energy released in $p$ - $n$ junction of PSD will be driven out to environment through the heat sinks. However, some part of it will be transferred into current-carrying parts through equalizing heat fluxes. In such a way thermal behavior of PSD will have effect on thermal behavior of another currentcarrying parts of power electronic equipment.

To determine equalizing heat fluxes let us use thermal equivalent circuit of most applied now press pack PSDs having two-side cooling shown in fig. 3 .

For the circuit represented the following equations are valid:

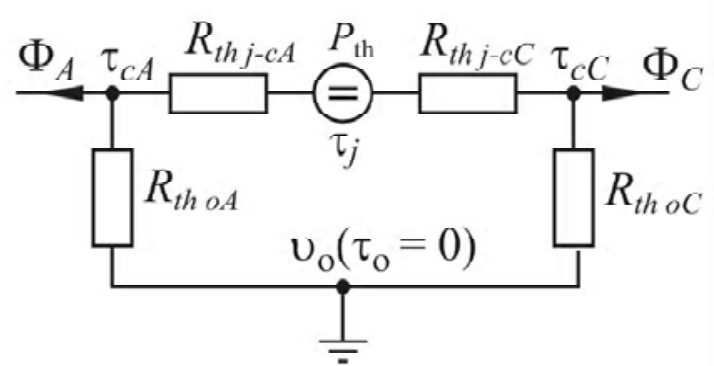

Fig. 3. Thermal equivalent circuit of PSD with two-side cooling

$$
\begin{aligned}
& P_{\mathrm{th}}=\frac{\tau_{j}-\tau_{c A}}{R_{t h j-c A}}+\frac{\tau_{j}-\tau_{c C}}{R_{t h j-c C}} ; \\
& \frac{\tau_{j}-\tau_{c A}}{R_{t h j-c A}}=\Phi_{A}+\frac{\tau_{c A}}{R_{t h o A}} ; \\
& \frac{\tau_{j}-\tau_{c C}}{R_{t h j-c C}}=\Phi_{C}+\frac{\tau_{c C}}{R_{t h o C}},
\end{aligned}
$$

where $P_{\text {th }}$ is thermal power released in $p-n$ junction of PSD at continuously flowing load current; $\tau_{j}$ is the temperature-rise of $p$ - $n$ junction of PSD; $\tau_{c A}, \tau_{c C}$ are the temperature-rises on anode and cathode terminals of the case, respectively; $\Phi_{A}$, $\Phi_{C}$ are equalizing heat fluxes incoming to current-carrying parts connected to anode and cathode of the PSD, respectively; $R_{t h j-c A}, R_{t h j-c C}$ are thermal resistances junction anode terminal and junction- cathode terminal of the case PSD, respectively, found in handbook [6]; $R_{\text {th } o A}, R_{\text {th oC }}$ are thermal resistances of individual heat sinks arranged on anode and cathode terminals of the PSD case, respectively.

Solution of equation (15) relatively equalizing heat fluxes gives:

$$
\begin{aligned}
& \Phi_{A}=s_{A}-\tau_{c A} u_{A}+\tau_{c C} v_{A} ; \\
& \Phi_{C}=s_{C}-\tau_{c C} u_{C}+\tau_{c C} v_{C},
\end{aligned}
$$

where the constants in expressions (16) are determined as follows:

$$
\begin{aligned}
& s_{A}=\frac{R_{t h j-c C}}{R_{t h j-c C}+R_{t h j-c A}} P_{\mathrm{th}} ; \\
& s_{C}=\frac{R_{t h j-c A}}{R_{t h j-c C}+R_{t h j-c A}} P_{\mathrm{th}} ; \\
& u_{A}=\frac{1}{R_{t h o A}}\left(1-\frac{R_{t h j-c C}}{R_{t h j-c C}+R_{t h j-c A}}\right)+\frac{1}{R_{t h j-c A}} ; \\
& u_{C}=\frac{1}{R_{t h o C}}\left(1-\frac{R_{t h j-c A}}{R_{t h j-c C}+R_{t h j-c A}}\right)+\frac{1}{R_{t h j-c C}} ; \\
& v_{A}=\frac{R_{t h j-c C}}{R_{t h o C}\left(R_{t h j-c C}+R_{t h j-c A}\right)} ; \\
& v_{C}=\frac{R_{t h j-c A}}{R_{t h o A}\left(R_{t h j-c C}+R_{t h j-c A}\right)} \cdot
\end{aligned}
$$


The analysis of the components typical for power electric and electronic equipment may be continued. However, the principle has remained the same. As the result of thermal behavior analysis of the current-carrying element the expressions for equalizing heat fluxes with unknown temperature-rises at the boundaries of considered element are to be derived.

Solution of the task to compute thermal behavior of the current-carrying system is to be performed in the following sequence:

1. The current-carrying system is to be subdivided into sections having the same heat transfer conditions, uniform material and relatively simple geometrical configuration.

2. Scheme of the current-carrying system including mentioned above types of sections is to be setup. Contact constriction regions are represented by separate sections in the scheme. The scheme must contain not only currentcarrying components of considered equipment, but the current-carrying parts to connect it into external circuit represented as half-infinite sections.

3. Using the expressions for equalizing heat fluxes and conditions of temperature field continuity at the sections boundaries the system of linear algebraic equations is to be setup. This system will include unknown temperature-rises at the sections boundaries.

4. Unknown temperature-rises are to be quantified by sequential approximations. It is due to non-linearity of initial differential equations (1) и (9), that is, due to temperature dependence of heat transfer coefficients, conductivity, resistivity etc.

5. Using expressions for temperature distribution of the current-carrying elements (4) and (7) as well as expressions for quantifying temperature-rises of contact spots (14) and $p-n$ junctions of PSDs (15), distribution of temperature throughout current-carrying system is evaluated.

It is evident that proposed approach to determine thermal behavior of inhomogeneous current-carrying system will be most effective, when computer software is used at all stages. However practical application experience of the proposed method shows that the real variant is the computer realization (as software) only at 4-th and 5-th stages with consideration of actual structure of the specific equipment current-carrying system.
Findings of test computations performed for currentcarrying system of on-load tap changer selector have shown qualitative coincidence of calculated temperature distribution with the results of temperature-rise tests. It should be pointed out that degree of quantitative coincidence is for the most part defined by adequateness of thermal equivalent circuit to real heat exchange processes in the current-carrying system. Therefore, one of most important and critical stage of the computation is to setup the structural scheme (outline the sections) and thermal equivalent circuits on its sections.

\section{REFERENCES}

1. Сахаров, П. В. Проектирование электрических аппаратов : [общие вопросы проектирования] / Сахаров П. В. - М. : Энергия, 1971.- 560 с.

2. Залесский, А. М. Тепловые расчеты электрических аппаратов / А. М. Залесский, Г. А. Кукеков. - Л. : Энергия, 1971. - $378 \mathrm{c}$.

3. Справочник по расчету и конструированию контактных частей сильноточных электрических аппаратов / [Адоньев Н. М., Афанасьев В. В., Борисов В. В. и др.]; под ред. В. В. Афанасьева. - Л. : Энергоатомиздат, 1988. - $384 \mathrm{c}$.

4. Никитенко, А. Г. Программирование и применение ЭВМ в расчетах электрических аппаратов / Никитенко А. Г., Гринченков В. П., Иванченко А. Н. - М. : Высшая школа, 1990. -231 с.

5. Белкин, Г. С. Тепловые процессы в электрических аппаратах / Белкин Г. С. - М. : Знак, 2006. - 224 с.

6. Чебовский, О. Г. Силовые полупроводниковые приборы : [справочник] / Чебовский О. Г., Моисеев Л. Г., Недошивин Р. П. - [2-е изд., перераб. и доп.]. М. : Энергоатомиздат, 1985. - $400 \mathrm{c.}$

7. Богданов, Л. Д. Методика расчета на нагрев контактных систем переключающих устройств трансформаторов/ Л. Д. Богданов, А. Л. Вайнштейн, В. М. Кораблев и др. // Электротехническая промышленность. Аппараты высокого напряжения, трансформаторы, силовые конденсаторы. - 1978. - Вып. 1 (81). - С. 8-12.

Стаття надійшла до редакиії 29.06.2011. Після доробки 05.09.2011.

\footnotetext{
А. В. Близняков

Анализ стационарного теплового режима токоведущих систем силового электрического и электронного оборудования

Предлагается методика расчетного определения стационарного теплового режима токоведущих систем силового электрического и электронного оборудования. Методика отличается значительной универсальностью и учитывает наличие в сложной токоведущей системе достаточно большого числа разнообразных элементов с различными условиями тепловыделения и теплоотдачи.

Ключевые слова: токоведущий элемент, токоведущая система, тепловой режим, нагрев, превыщение температуры, тепловой поток, тепловое сопротивление.

О. В. Близняков

Аналіз стаціонарного теплового режиму струмопровідних систем силового електричного та електронного обладнання

Пропонується методика розрахункового визначення стаціонарного теплового режиму струмопровідних систем силового електричного та електронного обладнання. Вона відрізнясться значною універсальністю та ураховує присутність в складній струмопровідній системі достатньо великої кількості різноманітних елементів з різноманітними умовами тепловиділення та тепловіддачі.

Ключові слова: струмопровідна система, тепловий режим, струмопровідний елемент, нагрів, перевищення температури, тепловий потік, тепловий опір.
} 